\title{
Violent Girls in the United States: Urban, Suburban, and Rural Differences ${ }^{1}$
}

Callie Marie Rennison

School of Public Affairs

University of Colorado Denver

Denver, CO

U.S.A. 80217

Walter S. DeKeseredy

Anna Deane Carlson Endowed Chair of Social Sciences,

Director of the Research Center on Violence, and

Professor of Sociology

West Virginia University

Contact author: Callie Marie Rennison: Callie.rennison@ucdenver.edu; +1 3033152813

\begin{abstract}
Though there is a rapidly growing social scientific literature on geographic variations in crime, it is still unclear whether rural girls are at greater or lesser risk of committing violent offenses than are their urban and suburban counterparts. This article uses 1992-2015 National Crime Victimization Survey (NCVS) data to help fill this research gap. The results show that there are significant differences in the rates of offending across geographic place. When considering offending rates for an aggregation of rape, sexual violence, robbery, aggravated assault and sexual assault, results indicate the highest rates of juvenile female offending in urban areas. The lowest juvenile female offending rates are found in rural areas. When excluding simple assault from the analysis (i.e., serious violence), juvenile female offending rates are highest in urban areas, but are similar in suburban and rural areas. While informative, this research highlights the need for greater research on this topic.
\end{abstract}

Keywords: girls, violence, geographic variations, National Crime Victimization Survey 


\section{Introduction}

Criminology has a long history of being urban-biased. However, as Donnermeyer (2016a) points out, "In the relatively short span of 20 years, the field of rural criminology has grown from the status of being mostly unknown to one that is now beginning to inform the broader field of criminology" (p. 1). Adding much to this advancement is the empirical and theoretical work of feminists who study rural male violence against women (Donnermeyer \& DeKeseredy, 2014). As well, such scholarly contributions marked the start of contemporary critical criminological analyses of rural crime (DeKeseredy, 2015). There are various definitions of critical criminology, but for the purpose of this article, it is termed a body of perspectives that view hierarchical social stratification and inequality along class, racial/ethnic, and gender lines as the major sources of crime and as the key factors that shape societal violations to legal and social norms (DeKeseredy \& Dragiewicz, 2014; Young, 1988). Defining feminism, too, is a topic of much debate, and there are at least 12 feminisms (Renzetti, 2013). Yet if, for convenience, we were to choose a simple definition of feminism, it might be useful to follow Daly and ChesneyLind (1988): "a set of theories about women's oppression and a set of strategies for change" (p. 502).

A review of the extant literature on rural crime and social control reveals that violence against women research monopolizes rural feminist criminological scholarship (DeKeseredy \& Dragiewicz, 2013; Rennison, DeKeseredy, \& Dragiewicz, 2013a, 2013b). There are, though, a few exceptions to the rule such as Grant's (2008) gendered analysis of Appalachian women's pathways from addiction to recovery, Smith's (2014) work on rural female drug injectors' struggles to manage the performance of their femininity, Rockell's (2013) study of rural druginvolved recidivist property and public order female offenders, and Little, Panelli, and Krack's (2005) research on rural women's fear of crime. Obviously, feminist rural criminological research on other topics is much needed. Of course, the same can be said about mainstream rural criminological research.

One way in which criminologists of all walks of life can fill gaps in rural criminology is the study of rural girls' violence. Consider that not one section of any chapter in Donnermeyer's (2016b) Routledge International Handbook of Rural Criminology discusses violent acts committed by rural girls. Except for the one written by DeKeseredy and Dragiewicz (2013), the same can be said about every chapter included in Renzetti, Miller, and Gover's (2013) Routledge International Handbook of Crime and Gender Studies. What is more, the word rural is not in Renzetti et al.'s (2013) index. These two comprehensive, ground-breaking books are, by no means, in the minority. Indeed, Irwin and Umemoto (2016) point to two common trends in the youth violence literature that account for the above editors being unable to include work like that featured in this article: 
First, criminologists have been rather male-focused for decades, with delinquent boys and criminal young men consistently in researchers' spotlight. Second, criminologists have focused on urban areas, which suburban, small-town, and rural locales are often overlooked (p. 8).

We would be, however, remiss if we did not briefly mention Swift's (2015) qualitative study of violent teenage girls in rural New Zealand. While offering a rich analysis of factors contributing to these girls' aggression, it remains unclear whether rural girls are at greater risk of committing violent acts than their urban and suburban counterparts (DeKeseredy, 2015). Doing rigorous feminist research on this issue is much more than an academic enterprise. Rich quantitative and qualitative data are needed to inform policies and services that help prevent girls' crime within the context of the specific communities where they live (Logan, Stevenson, Evans, \& Leukefeld, 2004).

Using 1992-2015 National Crime Victimization Survey (NCVS) data, this paper fills a major research gap by examining urban, suburban, and rural differences in girls' commission of violence in the United States. In particular, we do this by using the experiences of victims in urban, suburban, and rural locations who reported on the characteristics of offenders, by gender and age, to understand girls' comparative involvement in violence.

\section{Methods}

\section{Data}

The 1992-2015 NCVS data used come from a sample of housing units and group quarters in the United States (including Washington, D.C.) using a stratified, multistage, cluster design (Hubble, 1995; Rennison \& Rand, 2007). The survey is administered either in-person and over the phone to all people age 12 or older residing at an in-sample housing unit. Interviews are conducted every six months for a three and one-half year period (each person is interviewed twice in a year). This design in conjunction with subsequent weighting of the data, and use of specialized statistical software and analytic approaches results in findings representative of the non-institutionalized population of people age 12 or older in the United States.

NCVS data offer several advantages for the study of geographic variations in juvenile female violent offending. First, the large sample size enables an examination of specific types of violence (e.g., rural violence). Second, since the NCVS collects detailed incident-level information, many details about violence is available (e.g., the offender's sex). Third, NCVS data contain a more complete accounting for violence and offending because it includes both incidents reported and unreported to the police. This is important, given that a substantial amount of violence is not reported to the police (Hart \& Rennison, 2003; Rennison, 2002; Walklate, 
2017). ${ }^{2}$ Further, violence that is reported to the police differs greatly from that which is not reported. For example, an armed robbery or violence that injures people are most likely to be reported to the police (Walsh \& Hemmens, 2011). More generally, any violence involving weapons and injuries is more likely to be reported (Hart \& Rennison, 2003). Conversely, when violence does not include weapons or result in injuries, it is less likely to be reported to the police (Hart \& Rennison, 2003). Using data on both unreported and reported crimes means our research examines a more complete account of juvenile violent offenses than could be obtained from administrative records from law enforcement agencies who only have data on violence reported to them.

Still like all data, the NCVS is limited. One limitation is that offender characteristics are based on victims' perceptions and may be incorrect. While the potential for error in victim's perceptions exist, research suggests it is minimal (Hindelang, 1981). This may especially be the case when it comes to issues related to gender. A second limitation is that even though the NCVS can be used to estimate offending rates, it cannot provide violent offending prevalence estimates. This means that NCVS data cannot identify whether violent juvenile offending is the work of a few juveniles who commit a large amount of violence, or the work of many juveniles who commit a few offenses (Lynch, 2002). Another limitation is that the NCVS does not gather data on violence committed against persons under age 12, institutionalized people, or the homeless. What is more, the NCVS gleans data on a limited number of types of violence. This means that violent behaviors other than rape, sexual assault, robbery, aggravated and simple assault cannot be included in our analyses.

\section{Sample}

Several steps were taken to develop the sample used in our analyses. First, our analyses are restricted to 1992 to 2015 NCVS data. We begin with 1992 data as it is the first year of data available following a major break-in-series redesign of the NCVS. Post-redesign data offer improved measurement of violence and offending. The final year of data used is 2015 because it is the most recent year of data available at the time of analysis. On average, each year during this period, the sample included approximately 150,600 persons in 83,100 households. The average annual response rate during this time period was $92 \%$ for households and $89 \%$ for individuals. ${ }^{3}$ Second, our research focuses only on violence (i.e., no property offenses). Violence in the NCVS includes rape, robbery, aggravated assault and simple assault. Additional information about the violence included in this research, including definitions, is provided in the measures section below. Third, we restrict our analyses only to violence committed by females. In the NCVS, information about the sex of the offender is gathered from the victim. For incidents involving a single offender, only those cases where the victim identified a female offender were included. Incidents involving a single offender in which the sex of the perpetrator was unknown, a male, or the data were missing, were excluded from our analyses. In a multiple offender incident, the 
victim is not asked to reveal the demographic characteristics of each offender, but rather, the victim is asked about the characteristics of the group of offenders. ${ }^{4}$ An incident with multiple offenders can be described by the victim as all male, all female, mostly male, mostly female, or a mixed sex group. We included violence offenses committed when all offenders were female in our sample. In addition, following Lynch (2002), the analyses also include cases in which a group of offenders was described as "mostly female.” Offenses involving a single male, only males, or situations where victims could not identify the offenders' sex were removed from consideration. Additionally, groups of perpetrators described as "mixed” (but not mostly female) and all or mostly male were excluded from the analyses.

Finally, our research focuses only on violence committed by juveniles, defined here as a person age 12 to 17 years. Like sex, the age of the offender is provided by the victim. When the violent offense involved a single offender, only those cases where the victim identified as 12 to 17 years of age were included in this research. Offenses involving a single offender if the age of the perpetrator was unknown, older than 18, younger than 12, or the data were missing, were excluded from our analyses. Offenses involving multiple offenders were treated differently. If all offenders were described as between the ages of 12 and 17, the violent offenses were kept in the analysis. When multiple offenders included a "mixed group" of persons older than age 17, or younger than age 12, the offenses were excluded.

\section{Measures}

The primary measure in this research is geographic region which includes urban, suburban and rural areas. In each region, we provided estimated offending rates for total violence, as well as serious violence. Each of these measures are described in greater detail next.

Geographic Region: The primary measure of interest in this research is geographic region. The NCVS data includes a variable (v2129) that has historically been used to identify urban, suburban and rural areas (Dodge, 1985; DeKeseredy, Dragiewicz \& Rennison, 2012; Duhart, 2000; Lauritsen \& Heimer, 2008; Planty, et al., 2013; Rennison \& DeKeseredy, 2017; Rennison, DeKeseredy \& Dragiewicz, 2012; Rennison, DeKeseredy \& Dragiewicz, 2013a). This single measure comes from Office of Management and Budget (OMB) Metropolitan Statistical Area (MSA) designations. This OMB measure categorizes geographic areas into three categories based only on their relationship to a metropolitan area, or central city. Metropolitan Statistical Areas (MSAs) are bounded within a county or multiple counties. The first category in this measure is "City of (S)MSA." This is widely referred to in the extant literature as an "urban" area or "central city.” The second category is identified as "(S)MSA, Not City” which is commonly referred to as "suburban." The third category is labeled "Not (S)MSA)," which is commonly referred to as "rural” area. These geographic categories used in our study are consistent with research based on data collected by federal statistical agencies (Duhart, 2000). 
Because this measure comes directly from Census, it contains no missing data.

Violent Offending: The purpose of our research is to estimate and compare juvenile female offending rates in rural, suburban and urban areas. It would be ideal to accomplish this by examining a multitude of types of violence offenses separately (e.g., robbery alone, aggravated assault alone, etc.). However, analyses not shown here indicate that this level of disaggregation based on specific types of violent offending results in too few cases, especially for rural areas. Given that, our research focuses on total violence and serious violence only.

Total Violence: One measure of violence offending focused on in our analyses is total violence. Total violence includes rape, sexual assault, robbery, aggregated assault and simple assault. ${ }^{5}$ These types of violence are included regardless of whether they were completed or attempted. The NCVS defines rape as forced sexual intercourse that includes psychological coercion and physical force, heterosexual and same-sex rape, and rapes committed against males and females. Attempted rape includes verbal threats of rape. The NCVS defines sexual assault as distinct from rape or attempted rape. Sexual assault involves attacks or attempted attacks associated with unwanted sexual contact between victims and offenders. Sexual assaults may or may not involve force and include such behaviors as non-consensual grabbing, fondling, and verbal threats. Robbery is operationally defined as a completed or attempted theft, directly from a person, of property or cash by force or threat of force, with or without a weapon, and with or without injury. Aggravated assault is operationalized as an attack or attempted attack with a weapon, regardless of whether an injury occurred and an attack without a weapon when serious injury results. Simple assault is defined as a completed or attempted attack without a weapon resulting either in no injury, minor injury (e.g., bruises, black eyes, cuts, scratches or swelling) or an undetermined injury requiring less than two days of hospitalization.

Serious Violence: In addition, we provided analyses for a subset of total violence identified as serious violence. Serious violence includes rape, sexual assault, robbery, and aggregated assault. Unlike total violence, serious violence does not include simple assault. ${ }^{6}$

\section{Estimating offending rates}

This research focuses on rates of violent offending by juvenile females. Rates of juvenile female violent offending refer to the number of violent offenses committed by a juvenile female per 1,000 juvenile females. ${ }^{7}$ This offending rate per 1,000 is calculated as: ${ }^{8}$

[(\# incidents * \# offenders present)/population] * 1,000 = offending rate per 1,000 
This is equivalent to:

\section{[(\# offenses committed)/population] $* 1,000=$ offending rate per 1,000}

The numerator (the number of offenses) was estimated as a product of two values: the number of incidents multiplied by the number of offenders present at each incident. In a few instances, victims indicated a very high and improbable number of offenders were present during an incident. These cases were recoded to reflect a maximum of 10 offenders present (as per Lynch, 2002). The denominator is the population estimate provided in the public-use NCVS population data file. The denominator is based on the same unit as the numerator. For example, the denominator when calculating the rural juvenile female offending rate is the number of rural juvenile females (age 12-17). The denominator includes the aggregated population for the full time period (1992 to 1995) as the NCVS significance testing formulae require this approach.

\section{Analytic Strategy}

Our purpose is to compare female juvenile offending rates across geographic locations, namely, offending rates against persons in rural, suburban, and urban areas. Using analytic techniques found in off-the-shelf statistical programs that assume a simple random sample would underestimate the standard errors in the NCVS, and are thus not used. To account for the complex design of the NCVS, comparisons of estimates presented here use specialized formulae created by the Census Bureau made specifically for the NCVS. These tests use generalized variance function constant parameters to calculate variance estimates, standard errors, and confidence intervals. This avoids underestimation of standard errors as well as incorrect inferences about statistical significance that would result from treating estimates as if they came from a simple random sample. Caution is warranted when comparing estimated rates not explicitly discussed in the findings. What may appear to be a large difference between two estimates may not be statistically different. In contrast, seemingly similar estimates may in fact be statistically different. All estimates and comparisons reported are based on data that has been weighted using the appropriate weights found in the public-use data files.

\section{Results}

We begin by estimating and comparing total violent offenses committed by female juveniles in urban, suburban and rural places. The data used for these analyses included 6,537,151 (weighted) violent incidents involving juvenile females from 1992 to 2015. Because some of these violent incidents involved multiple juvenile females, the offending counts are greater. As shown in Table 1, between 1992 and 2015, a total of 8,380,278 violent offenses were committed by female juveniles. About one-third (34.0\%) of total violent offenses were 
committed by juvenile females in urban places. In contrast, about half (50.9\%) of female juvenile violent offenses occurred in suburban areas, and $15.6 \%$ in rural locales.

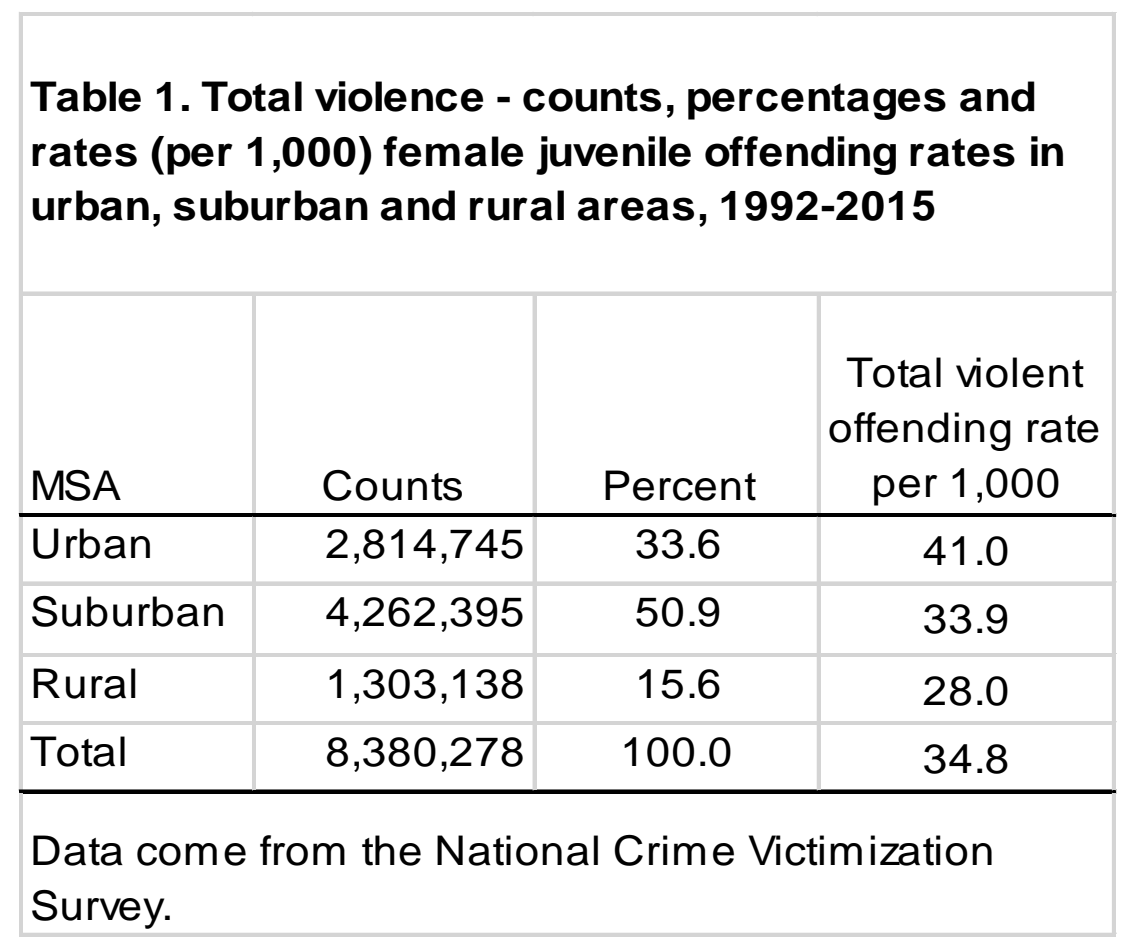

Note: Statistically significant differences between offending rates at the $\mathrm{p}<.05$ level are measured among all geographic areas.

Our findings estimate juvenile female total violent offending rates of 41.0 (per 1,000 female juveniles) in urban settings, compared to 33.9 in suburban places, and 28.0 in rural areas. Statistical tests indicate differences in total violent offending rates across the three geographic areas. The female juvenile total offending rate against victims living in urban areas is significantly greater than the offending rates in suburban and rural areas $(\mathrm{p}<.05)$ Similarly, the female juvenile total offending rate in suburban places is significantly greater than that in rural areas $(\mathrm{p}<.05)$ (see Table 1$)$. These findings suggest that the more urbanized an area, the higher the rate of female juvenile total offending.

We next examine a subset of total violence - serious violence. As stated above, serious violent offenses include rape, sexual assault, robbery and aggravated assault. Simple assault is not included in estimates of serious violence offending. Following the aforementioned restrictions, the serious violence file included 994,007 serious violent incidents that occurred from 1992 to 2015. Since some of these incidents involved multiple female juvenile perpetrators, the count of offenses is greater. Table 2 shows a total of 1,447,902 serious violent offenses were committed by female juveniles from 1992 to 2015. Less than half of these serious offenses took place against those living in urban areas (44.0\%). About forty percent (39.5\%) of serious violence offenses were committed against those living in suburban places, and $16.4 \%$ occurred 
against those in rural places. An assessment of differences in serious violence offending rates by female juveniles indicates a serious offending rate of 9.3 (per 1,000) against those living in urban settings, compared to 4.6 (per 1,000) in suburban places, and 5.1 in rural places. Statistical testing shows that the serious female juvenile offending rate against victims in urban areas is significantly greater than those against persons in suburban and rural areas $(\mathrm{p}<.05)$. While the rates of suburban and rural female juvenile serious offending rates appear different in Table 2, statistical testing indicates that they are in fact statistically equal. That is, the rate of female juvenile serious offending is similar in suburban and rural areas.

\begin{tabular}{|c|c|c|c|}
\hline MSA & Counts & Percent & $\begin{array}{l}\text { Total violent } \\
\text { offending rate } \\
\text { per } 1,000\end{array}$ \\
\hline Urban & 637,429 & 44.0 & 9.3 \\
\hline Suburban & 572,639 & 39.5 & 4.6 \\
\hline Rural & 237,833 & 16.4 & 5.1 \\
\hline Total & $1,447,901$ & 100.0 & 6.0 \\
\hline
\end{tabular}

Note: Statistically significant differences between offending rates at the $\mathrm{p}<.05$ level are measured between urban and the other geographic areas. No significant differences between offending rate estimates are measured between suburban and rural areas.

\section{Discussion}

The research reported here helps fill a vacuum in the literature on geographic variations in female juvenile violent offending. Further, this study answers the call to go beyond using census and official arrest data to examine youth violence and other crimes that occur in rural places (DeKeseredy \& Schwartz, 2009; Donnermeyer \& DeKeseredy, 2014; Osgood \& Chambers, 2000). Note that the bulk of the extant research on rural youth violence use law enforcement data or school report statistics (Glosser, 2016; Weisheit \& Wells, 2001). Even so, our results need to be read with caution for several reasons, one of which is the nature of the sample. For instance, 
while the NCVS is a very large national U.S. study, it captures a small amount of data from each part of the country. Though we aggregated the rural, suburban, and rural data over time, and can make generalizations about crime victimization in these three types of places, the Home Office's critique of the British Crime Survey (BCS) ${ }^{9}$ is relevant here. This agency reminds us that since the NCVS, like the BCS, is a national survey, "it cannot provide detailed information about the extent and impact of crime in particular neighborhoods or communities. However, crime tends to be geographically concentrated and its impact in those places is correspondingly more severe" (H.O.R.U., 1984, p. 5). So, we cannot reach strong conclusions about any particular area using the NCVS (Pease, 1992), but we do know from the literature that rural rates of crime may be higher than urban and suburban rates at particular types of rural places and for specific types of crime (Donnermeyer, 2016b; Donnermeyer \& DeKeseredy, 2014). Perhaps, then, if a series of in-depth studies of particular rural places were done, data challenging our findings on geographic variations would be uncovered. Such research may also find that differences across place exist for some types of female juvenile violent offending and not others. Aggregating different types of offending as we did may mask these important type of crime variations that may be revealed with new types of research or additional years of NCVS data.

Another word of caution arises from the NCVS' operationalization of place. The measure of urban, suburban and rural is based on where the victim lives and not necessarily where the violence took place. The impact of this shortcoming, however, should be minimized given that most violence occurs near the victim's home (especially for women) (Catalano, n.d.; Planty, Langton, Krebs, Berzofsky, \& Smiley-McDonald, 2013; Sinozich \& Langton, 2014). Still, it is important to note that we are unable to discern how many people were victimized at a place other than where they live.

In addition to addressing the above concerns, theoretical work on rural female juvenile violence is sorely needed. Girls' violence in urban places is generally explained by feminists as a "response to patriarchal conditions" (Irwin \& Umemoto, 2016, p. 11). Is this also the case in rural communities? Or, is some rural girls' violence motivated by gender inequality and some of it influenced by the same factors that motivate boys to engage in violence (Miller, 2001), such as racial, political, and economic alienation (Irwin \& Umemoto, 2016; Simpson, 1989, 1991)? Possibly, "multiple oppressions" theories may best explain rural female youth violence (BurgessProctor, 2006; Chesney-Lind \& Morash, 2013; Richie, 2012). As is often stated, more research is necessary to provide answers to the theoretical questions raised here.

Despite the aforementioned limitations, the NCVS offered a valuable opportunity to start investigating geographic variations in female juvenile violent offending, and this study provides a solid foundation on which future research should build. Certainly, it is now time to move well beyond limiting youth violence research to the study of urban boys in deindustrialized communities. Nonetheless, while there is a need for much more empirical and theoretical work 
on rural girls, rural boys' violence has also received short shrift from the criminological community. Hence, we can confidently conclude that the growing literature on rural violence is still incomplete (Donnermeyer, 2016c).

\section{Endnotes}

${ }^{1}$ This is a revised version of a paper presented at the November 2016 annual meetings of the American Society of Criminology meetings, New Orleans, LA. The authors would like to thank Meda Chesney-Lind, Joseph F. Donnermeyer, Katherine Irwin, James Nolan, and Martin D. Schwartz for their comments. Please send all correspondence to Callie Marie Rennison.

2 This is especially the case with male-to-female violence in intimate heterosexual relationships and with violence in same-sex relationships (DeKeseredy, Dragiewicz, \& Schwartz, 2017; Guadalupe-Diaz, 2015).

${ }^{3}$ See Rennison and Rand (2007) for more detailed information on NCVS methodology.

${ }^{4}$ Given the way the NCVS deals with violence involving multiple offenders, it is not possible to offer a count of the number of offenders.

${ }^{5}$ See http://www.bjs.gov/content/pub/pdf/cvus/cvus06mt.pdf for full definitions of each.

${ }^{6}$ See http://www.bjs.gov/content/pub/pdf/cvus/cvus06mt.pdf for full definitions of each.

${ }^{7}$ This is distinct from victimization rates that focus on the number of victimizations per 1,000 people. It also differs from incident counts in that one can have multiple offenses (or victimizations) in one incident.

${ }^{8}$ Incidents are distinct from offenses. An incident can include multiple offenses, as well as multiple offenders, and multiple victims.

${ }^{9}$ This survey is now called the Crime Survey for England and Wales (CSEW). 


\section{References}

Burgess-Proctor, A. (2006). Intersections of race, class, gender, and crime: Future directions for feminist criminology. Feminist Criminology, 1, 27-47. https://doi.org/10.1177/1557085105282899

Catalano, S. (n.d.). Intimate partner violence in the United States. Retrieved from https://www.bjs.gov/content/pub/pdf/ipvus.pdf.

Chesney-Lind, M., \& Morash, M. (2013). Transformative feminist criminology: A critical rethinking of a discipline. Critical Criminology, 21, 287-304. https://doi.org/10.1007/s10612-013-9187-2

Daly, K., \& Chesney-Lind, M. (1988). Feminism and criminal justice. Justice Quarterly, 5, 497538. https://doi.org/10.1080/07418828800089871

Dodge, R.W. (1985). Locating city, suburban and rural crime. Washington, DC: U.S. Department of Justice, Bureau of Justice Statistics.

DeKeseredy, W. S., Dragiewicz, M., \& Rennison, C. M. (2012). Racial/Ethnic variations in violence against women: Urban, suburban, and rural differences. International Journal of Rural Criminology, 1, 184-202. https://doi.org/10.18061/1811/53699

DeKeseredy, W. S. (2015). New directions in feminist understandings of rural crime. Journal of Rural Studies, 39, 180-187. https://doi.org/10.1016/j.jrurstud.2014.11.002

DeKeseredy, W. S., \& Dragiewicz, M. (2013). Gaps in knowledge and emerging areas in gender and crime studies. In C. M. Renzetti, S. L. Miller, \& A. R. Gover (Eds.), Routledge international handbook of crime and gender studies (pp. 297-307). London: Routledge.

DeKeseredy, W. S., \& Dragiewicz, M. (2014). Introduction: Moving forward, looking back. In W. S. DeKeseredy \& M. Dragiewicz (Eds.), Critical criminology, volume 1 (pp. 1-16). London: Routledge.

DeKeseredy, W. S., Dragiewicz, M., \& Schwartz, M. D. (2017). Abusive endings: Separation and divorce violence against women. Oakland, CA: University of California Press.

DeKeseredy, W. S., \& Schwartz, M. D. (2009). Dangerous exits: Escaping abusive relationships in rural America. New Brunswick, NJ: Rutgers University Press. 
Donnermeyer, J. F. (2016a). Introduction to the International handbook of rural criminology. In J. F. Donnermeyer (Ed.), The Routledge international handbook of rural criminology (pp. 1-13). London: Routledge.

Donnermeyer, J. F. (Ed.). (2016b). The Routledge international handbook of rural criminology. London: Routledge.

Donnermeyer, J. F. (2016c). Violence and rurality. In J. F. Donnermeyer (Ed.), The Routledge international handbook of rural criminology (pp. 167-169). London: Routledge.

Donnermeyer, J. F., \& DeKeseredy, W. S. (2014). Rural criminology. London: Routledge.

Duhart, D. T. (2000). Urban, suburban, and rural victimization, 1993-98. Washington, DC: U.S. Department of Justice, Bureau of Justice Statistics, NCJ 195710.

Glosser, A. M. (2016). Homies of the corn: Gangs in the rural environment. In J. F. Donnermeyer (Ed.), The Routledge international handbook of rural criminology (pp. 8592). London: Routledge.

Grant, J. (2008). Charting women's journeys: From addiction to recovery. Lanham, MD: Lexington Books.

Guadalupe-Diaz, X. (2015). Same-sex victimization and the LGBTQ community. In T. N. Richards \& C. D. Marcum (Eds.), Sexual victimization: Then and now (pp. 173-192). Thousand Oaks, CA: Sage. https://doi.org/10.4135/9781483398396.n10

Hart, T.C., \& Rennison, C.M. (2003). Reporting Crime to the Police. Washington, DC: U.S. Department of Justice, Bureau of Justice Statistics, NCJ 195710.

Hindelang, M. J. (1981). Variations in sex-race-age-specific incidence rates of offending. American Sociological Review, 46. 461-474. https://doi.org/10.2307/2095265

H.O.R.U. (1984). Research program, 1984-1985. London: HMSO.

Hubble, D. L. (1995). The national crime victimization redesign: New questionnaire and procedures development and phase-in methodology. Paper presented at the annual meetings of the American Statistical Association, Orlando, FL.

Irwin, K., \& Umemoto, K. (2016). Jacked up and unjust: Pacific Islander teens confront violent legacies. Oakland, CA: University of California Press. 
Violent Girls in the United States: Urban, Suburban, and Rural Differences - Rennison and DeKeseredy

Lauritsen, J.L. \& Heimer, K. (2008). Gender and Violent Victimization, 1973-2004. Journal of Quantitative Criminology, 24, 125-147. https://doi.org/10.1007/s10940-008-9041-y

Little, J., Panellis, R., \& Kraack, A. (2005). Women’s fear of crime: A rural perspective. Journal of Rural Studies, 21, 151-163. https://doi.org/10.1016/j.jrurstud.2005.02.001

Logan, T. K., Stevenson, E., Evans, L., \& Leukefeld, C. (2004). Rural and urban women’s perceptions for barriers to health, mental health, and criminal justice services: Implications for victim services. Violence and Victims, 19, 37-62. https://doi.org/10.1891/vivi.19.1.37.33234

Lynch, J. P. (2002). Trends in juvenile violent offending: An analysis of victim survey data. Washington, D.C.: Office of Juvenile Justice and Delinquency Prevention.

Miller, J. (2001). One of the guys: Girls, gangs, and gender. New York: Oxford University Press.

Osgood, D. W., \& Chambers, J. M. (2000). Social disorganization outside the metropolis: An analysis of rural youth violence. Criminology, 38, 81-115. https://doi.org/10.1111/j.17459125.2000.tb00884.x

Pease, K. (1992). The local crime survey: Pitfalls and possibilities. In J. Lowman \& B. D. MacLean (Eds.), Realist criminology: Crime control and policing in the 1990s (pp. 303312). Toronto: University of Toronto Press.

Planty, M., Langton, L., Krebs, C., Berzofsky, M., Smiley-McDonald, H. (2013). Female victims of sexual violence, 1994-2010. Washington, DC: U.S. Department of Justice, Bureau of Justice Statistics, NCJ 240655.

Rennison, C.M. (2002). Rape and Sexual Assault: Reporting to Police and Medical Attention, 1992-2000. Washington, DC: U.S. Department of Justice, Bureau of Justice Statistics, NCJ 194530.

Rennison, C.M., \& DeKeseredy, W.S., (2017). Situational contexts of rural violence: A comparison of male and female perpetration. Journal of Contemporary Criminal Justice, 33(2), 1-18. https://doi.org/10.1177/1043986216688813

Rennison, C. M., DeKeseredy, W. S., \& Dragiewicz, M. (2012). Urban, suburban, and rural variations in separation/divorce rape/sexual assault. Feminist Criminology, 7, 282-297. https://doi.org/10.1177/1557085111435660 
Rennison, C. M., DeKeseredy, W.S., \& Dragiewicz, M. (2013a). Intimate relationship status variations in violence against women: Urban, suburban, and rural differences. Violence Against Women, 19, 1312-1330. https://doi.org/10.1177/1077801213514487

Rennison, C. M., DeKeseredy, W. S., \& Dragiewicz, M. (2013b). Context matters: Violence against women and reporting to police in rural, suburban, and urban areas. American Journal of Criminal Justice, 38, 141-159. https://doi.org/10.1007/s12103-012-9164-4

Rennison, C. M., \& Rand, M. (2007). Introduction to the national crime victimization survey. In J. P. Lynch \& L. A. Addington (Eds.), Understanding crime statistics: Revisiting the divergence of the NCVS and the UCR (pp. 17-54). New York: Cambridge University Press.

Renzetti, C. M. (2013). Feminist criminology. London: Routledge.

Renzetti, C. M., Miller, S. L., \& Gover, A. R. (Eds.). (2013). Routledge international handbook of crime and gender studies. London: Routledge.

Richie, B. (2012). Arrested justice: Black women, violence, and America's prison nation. New York: New York University Press.

Rockell, B. A. (2013) Women and crime in the rural-urban fringe. International Journal of Rural Criminology, 2, 53-74. https://doi.org/10.18061/1811/58847

Simpson, S. (1989). Feminist theory, crime, and justice. Criminology, 27, 607-631. https://doi.org/10.1111/j.1745-9125.1989.tb01048.x

Simpson, S. (1991). Caste, class, and violent crime: Explaining differences in female offending. Criminology, 29, 115-135. https://doi.org/10.1111/j.1745-9125.1991.tb01061.x

Sinozich, S. \& Langton, L. (2014). Rape and sexual assault victimization among college age females, 1995-2013. Washington, DC: U.S. Department of Justice, Bureau of Justice Statistics, NCJ 248471.

Smith, C. (2014). Injecting drug use and the performance of rural femininity: An ethnographic study of female injecting drug users in north Wales. Critical Criminology, 22, 511-525. https://doi.org/10.1007/s10612-014-9252-5 
Swift, D. (2015). Battling for survival: The struggles of teenage girls in rural New Zealand. Paper presented at the Inaugural Asia-Pacific Conference on Gendered Violence \& Violations, University of New South Wales, Sydney, Australia.

Walklate, S. (2017). Criminology: The basics ( $3^{\text {rd }}$ ed.). London: Routledge.

Walsh, A., \& Hemmens, C. (2011). Measuring crime and criminal behavior. In A. Walsh \& C. Hemmens (Eds.), Introduction to criminology: A text/reader ( $2^{\text {nd }}$ ed.) (pp. 32-46). Thousand Oaks, CA: Sage.

Weisheit, R. A., \& Wells, L. E. (2001). The perception of gangs as a problem in nonmetropolitan areas. Criminal Justice Review, 26, 170-192. https://doi.org/10.1177/073401680102600203

Young, J. (1988). Radical criminology in Britain: The emergence of a competing paradigm. British Journal of Criminology, 28, 159-183. https://doi.org/10.1093/oxfordjournals.bjc.a047723 